\title{
Perspective \\ Conflicts of Interest Arising from Simultaneous Service by Editors of Competing Journals or Publishers
}

\author{
Jaime A. Teixeira da Silva
}

check for

updates

Citation: Teixeira da Silva, J.A Conflicts of Interest Arising from Simultaneous Service by Editors of Competing Journals or Publishers. Publications 2021, 9, 6. https:// doi.org/10.3390/publications9010006

Received: 8 December 2020

Accepted: 3 February 2021

Published: 8 February 2021

Publisher's Note: MDPI stays neutral with regard to jurisdictional claims in published maps and institutional affiliations.

Copyright: (C) 2021 by the author. Licensee MDPI, Basel, Switzerland. This article is an open access article distributed under the terms and conditions of the Creative Commons Attribution (CC BY) license (https:// creativecommons.org/licenses/by/ $4.0 /)$.
Independent Researcher, P.O. Box 7, Ikenobe 3011-2, Kagawa-ken 761-0799, Japan; jaimetex@yahoo.com

\begin{abstract}
In this day and age of challenging post-publication peer review and heightened academic scrutiny, editors serve an increasingly important role in screening submissions and managing the quality of information that is published in scholarly journals. Publishers compete for an intellectual market while commercial publishers compete for a commercial share of the market. The assumption argued in this perspective is that having editorial positions in competing journals or publishers (CJPs) may represent competing intellectual, professional and/or financial interests. Thus, based on this assumption, an editor would be expected to show loyalty to a single entity (journal or publisher). Editorial positions on the editorial boards of CJPs, as well as conflicts, financial or other, should be clearly indicated for all editors on the editorial board page of a journal's website, for transparency. In science and academia, based on these arguments, the author is of the belief that editors should thus generally not serve on the editorial boards of CJPs, or only under limited and fully transparent conditions, even if they serve as editors voluntarily. The author recognizes that not all academics, including editors, might agree with this perspective, so a wider debate is encouraged.
\end{abstract}

Keywords: accountability; bias; collective self-deception; conflict of interest; editorial responsibility; open access mega journal; peer review and post-publication peer review; predatory publishing; quality control; transparency

\section{Editors' Responsibilities in Academic Publishing: A Debate on Hidden Conflicts}

Editors are one essential component that contributes to the survival and continuity of a journal, especially in a highly competitive academic market where there are multiple competing journals and publishers (CJPs). What is often rarely known publicly, because editorial selection processes are almost always opaque and veiled from the public and academia, is how editors and editors-in-chief (EICs) are selected, based on what criteria, and with what qualifications [1]. Such opacity is antithetic to basic tenets of open science [2]

Editors have a wide range of responsibilities [3]: they are responsible for and are expected to safeguard the integrity of the literature that is published in their journals, as well as to ensure honest reporting of research findings, make decisions based on principles of fairness, respect, lack of bias or conflicts of interest (COIs), i.e., impartiality, and transparently implement and verify clear, visible and publishing policies, including those related to misconduct, post-publication peer review, whistle-blowing and the respect of authors' rights, including challenges to editors. As a subset of their responsibilities toward academia and the public, editors' COIs should be clearly indicated on their public curriculum vitae (CVs) [4] and on journals' web pages of editorial boards [5]. Despite this natural assumption, such details are frequently not observed for editors on editorial boards, even of journals that claim to espouse ethical standards established by the Committee on Publication Ethics (COPE) and the International Committee of Medical Journal Editors (ICMJE) [6].

As journals and publishers employ social media to promote journal content, policy and perspectives, social media editors have the responsibility of offering a promotive role and engaging proactively with the academic community and the public, but such editors 
might feel that their efforts are underappreciated and insufficiently rewarded [7], while the potential risk of offering a biased "positive" perspective of a journal is an issue that has yet to be debated.

Some editors or EICs, referred to as "zombie" editors, remain on the editorial boards of journals despite having a proven public record of erroneous literature, misconduct and/or debatable ethical stances [8]. Such editors are a risk to editorial integrity because they can, via bias, influence the flow of ideas in the literature [9]. Should such CJPs not be called out, and should editors or EICs that serve on their boards not be removed from their editorial position, based on the principle that they have violated basic principles of honesty [10]? Some editors continue to exist on editorial boards, even after they have deceased [11]. These editors need to be promptly removed from the editorial board to reflect an accurate editorial constituency but should form part of a historical "former" editorial board member list of former and deceased editors that publicly recognizes their often voluntary contribution, similar to unpaid peer reviewers [12], to the journal and to its standing. Deceased "former" editors can be simply indicated by a " $\dagger$ " mark.

High ethical standards, especially pertaining to openness and transparency, are required of editors because they have a responsibility that extends beyond the self and impacts both their academic community (sensu stricto) and the public (sensu lato) [13].

\section{Editors' Hidden and Stated Conflicts of Interest}

When COIs are deliberately or intentionally concealed, this constitutes an ethical infraction [14,15], and is equivalent to, and a form of, cheating [16]. This ethical infraction may be compounded by the failure to recognize it as such, either through denial or avoidance [17,18], due to moral stagnation [19] or moral dissonance [20], resistance to disclose a hidden COI, the inability to appreciate an undeclared editorial position on a CJP editorial board as a moral issue, or due to peer pressure not to disclose such a competing position [21]. In any of these cases, the greatest risk is that an empowering or impositional editor, or an editor of higher rank, such as an EIC, might impose their moral stance on other editors, thereby "forcing" them to adopt the same (un)ethical or morally dubious stance. In academic publishing, no term currently exists to describe a situation in which an editor might be forced, or feel pressure, to retire from the editorial board for not conforming to ethical standards they do not agree with or abide by. The closest concept to describe an individual that forces another individual to accept a moral stance against their will is coercion. When such behavior extends itself to the entire editorial board, or to all journals under a publisher's umbrella, without due recognition of the intrinsic moral lapse, then failure may be institutional [22]. In academic publishing, this is at the level of editorial board, journal or publisher. Medical education is one field of research that is apparently suffering from hidden COIs [23].

There are likely also editors who serve on the editorial boards of CJPs that cannot appreciate the existence of dishonesty in hidden or undeclared COIs because they hold a "morally superior" belief that their position, even if potentially unethical, is somehow morally defensible [24] because they feel they are performing an act of "greater good" for the academic community, namely editing work. Moral disengagement, specifically attempted moral justification for a morally indefensible position, as can be observed in some corporate circles [25], has not been discussed much within academic publishing. Such editors, who are oblivious of their own hidden COIs or who deny their existence, but who expect the authorship that they preside over to declare such COIs, not only display a moral sense of entitlement, they also exercise ethical exceptionalism or a dual structure of morals [26]. Consequently, the journals they represent display a disorganized fractured moral structure [27]. Is turning a blind eye to hidden editorial COIs the "cost" of editorial contribution [28]? If so, is a journal whose editors hide, conceal or fail to reveal COIs in need of managerial restructuring [29] or moral reengineering and reeducation [30] to appreciate their flawed ethical position? 
The ICMJE provides a simple COI form in PDF format that could be completed within a few minutes, even less when there are no COIs to declare, and such a form could be easily posted online at a journal's website, so there are few functional or structural excuses for editors to not display COIs. An editor without COIs has the simplest statement of all: "<Name> declares no conflicts of interest". Even this simple bureaucratic addition, similar to a signature signed before a report is assigned as opposed to after [31], could have a positive impact on decreasing dishonesty as well as increasing transparency and accountability, although the seriousness with which authors sign COI forms, and how COIs can be independently verified, merits more study.

\section{When Editors Protest Moral, Ethical or Ideological Differences with Journals or Publishers}

The mass conformation of an editorial board to abide by ethical standards is the standard and expected practice, or the golden rule, while the mass conformation of an editorial board to abide by unethical standards is incomprehensible and unacceptable. The latter is fortified by cases of mass resignation of editors that protest what they collectively perceive to be an unethical or unacceptable stance or practice by a publisher, as was briefly suggested in the previous section, highlighted by several (non-exhaustive set of) examples next.

The mass resignation of the entire editorial board of Wiley's European Law Journal was to protest the loss of academic freedom to make editorial member selections [32]. Most on the editorial board of Wiley's Diversity and Distributions protested the publisher's apparent interference in editorial independence as well as the journal's transition to a costly open access (OA) article processing cost (APC)-based publishing model [33]. Wiley rebutted the former claims [34]. The protest actions by Diversity and Distributions editors reflected greater concerns and upheaval that academics and academic societies face during the transition to an OA APC-based model from a subscription-based model [35]. To protest the publisher's OA policies, or lack thereof, the entire editorial board of Elsevier's Journal of Combinatorial Theory, Series A resigned and established their own independent OA journal, Combinatorial Theory [36]. The protest of OA fees or APCs is not a new phenomenon at Elsevier, and in 2015, the entire editorial board of Lingua resigned en masse to protest excessively high APCs and to start a new OA journal, Glossa [37]. Similarly, the entire editorial board of Elsevier's Journal of Informetrics resigned en masse to protest excessively high APCs, starting a new OA journal, Quantitative Science Studies, published by MIT Press [38]. A Springer Nature OA mega journal, Scientific Reports, saw the resignation of 19 Johns Hopkins researchers from its editorial board after the journal refused to retract a paper based on claims of plagiarism, and even though the paper was eventually retracted [39], the editors that had resigned were apparently not reinstated to the journal's editorial board. A Taylor \& Francis journal, Building Research and Information, saw the mass resignation of members of its editorial board after the publisher forcefully attempted to terminate the contract of its EIC [40].

These cases indicate clearly that there can be serious and deep moral, intellectual and ethical differences between editors and the journals or publishers they serve, as well as struggles for editorial independence and unity, fortifying the notions that editorial conflicts are real, tangible, have real-life consequences and that positions in CJPs should be declared. Thus, the editors of these new off-shoot journals that are the product of protest and dissent have the responsibility of noting their moral or ethical position in COI statements on the editorial board pages of journals and on their CVs, as well as their active involvement and participation in these conflicts. If pride was taken in showing dissent, and if personal and professional sacrifice accompanied a firm moral stance, then the failure of dissenting editors to declare their actions and position in COI statements on the editorial board pages of the new journal and on their CVs would, to some extent, ironically speak to a lack of transparency. Secrecy, shame, regret or fear of reputational harm are the most plausible explanations for hiding true aspects such as COIs [41]. 


\section{The Global Publishing Market: Editors Might Serve in Competing Journals or Publishers}

Global publishing is a highly competitive and extremely profitable, multi-billiondollar market with CJPs vying not only for intellectual property rights, but also a larger market space with models that can sometimes be perceived as being exploitative [42]. Editors benefit from performing their tasks (e.g., experience, knowledge mining), but the exploitation of labor arises since the market has few buyers (i.e., standalone journals or publishers) of these labor services, depressing the wage rate below what it would be if the market had many buyers [42], i.e., the proverbial "squeezing the lemon dry" [12]. However, in this scenario, it is likely that demand for highly qualified editors outweighs supply, so one can frequently observe editors who serve on the editorial boards of one or more CJPs. Some possible or plausible reasons why this may be are: (1) the supply of highly qualified editors with suitable expertise is very restricted [43]; (2) the wages paid to be an editor are so low that demand for these services exceeds the supply of services (the market is big enough to keep wages suppressed), i.e., an editor "market" in which editors are treated as "dispensable" or "replaceable" assets; (3) if editors are not paid for their services, why would they want to serve, apart from prestige? In this case, quantity supplied is low and quantity demanded is high since the market product (journals) is expanding [44]; (4) underpaid labor leads to loss of motivation, and poor motivation in turn stimulates bad work [45]. This may result in demotivated editors, editorial oversight and subsequently the escape of "bad" science into the literature stream that did not receive sufficiently rigorous editorial review. Curiously, there does not seem to be any literature pertaining to the loss of editorial motivation within an academic publishing context, especially as it becomes exposed to an increasing number of threats to its integrity, placing a greater weight of responsibility on the shoulders of editors. This issue needs to be urgently researched.

In this highly lucrative-but competitive-academic publishing industry that is also threatened by "predatory" journals or publishers, entities that it is still unable to classify with clarity and unable to effectively deal with [46], the desire (perhaps even desperation) to hold on to free highly skilled editorial labor may be a matter of survival or death for CJPs. The failure of a journal, publisher or editors to strictly uphold ethical principles they espouse in public on their journal websites should count toward their classification as "predatory" [47]. Even though the precise identity of "predatory" journals or publishers remains unclear [46], one "predatory" characteristic is irrefutable, namely the failure to uphold established ethical publishing principles [48].

\section{Editors in Competing Journals and Publishers: Professional and Ethical Considerations}

In this highly conflicted, competitive and exploitative publishing environment, journals will likely, but understandably, attempt to retain and defend their editors and EICs, even those in CJPs, independent of or oblivious to the conflicts that these pose. However, in an academically corporate publishing market [49], positions-including apparently contradictory (e.g., billion-dollar profits versus free labor) ones-may be morally indefensible.

An addition was made to a white paper published by the Council of Science Editors (CSE), in May of 2018, pertaining to editors or EICs in CJPs [50]. That addition offers several relevant fascinating statements and discussion points, indicated as verbatim quotations, with additional notes by the author:

1. "Importantly, these considerations are most relevant to situations where the editor has decision-making authority over manuscripts for more than one journal and/or influence on more than one journal's editorial policies." Decision-making authority over manuscripts that are submitted to competing journals, which may also involve the selection of peer reviewers [51], might compromise editorial neutrality, especially if they are linked to editorial policies. Inherent bias, including selection bias [52], might favor publications sent to one CPJ over another if handled by the same editor. To eliminate such bias, should editors have their right to editorial independence, or should their principles and guidelines be guided by "outsourced" guidelines 
(e.g., those created by COPE or the ICMJE)? Not only is there an increasing call for editorial independence from economic and political interests [53], but also from external "ethical" influence.

2. "Having the same scholar as gatekeeper for manuscripts on any given subject area for more than one of the primary journal outlets in a field is unhealthy because it gives that person undue influence over what is being published in that field." This statement is self-explanatory, but the issue would become more acute as the field of study becomes narrower and, thus, the number of available expert editors becomes scanty. This statement is also fascinating because it suggests that, to some extent, editors can influence the literature or control the flow of information, either by controlling what gets accepted and released into the literary domain or blocked through rejection.

3. " $[$... ] researchers should disclose all of their existing editorial board commitments when they are approached about taking on an additional editorial role and the editors who are recruiting them should take those other commitments into consideration." This suggests that editors and EICs of CJPs should refrain from accepting individuals to their editorial board if knowledge of this COI exists. In other words, editors and EICs should make a conscientious decision to support only a single journal. This raises the issues of editorial "ownership" (i.e., do journals or publishers "own" editors?) and editorial "exclusivity" (i.e., do journals or publishers expect "their" editors to only/exclusively assist/serve them?), especially if they are under contract with term limits. The issue of editorial ownership and its intersection with editorial independence is considerably well explored and debated in journalism [54], but not in academic publishing. Regarding the issue of exclusivity, the content of such contracts or agreements is generally unknown because they are likely limited by confidentiality or non-disclosure clauses, but this issue needs to be explored in detail because it is another opaque aspect of academic publishing that limits the ability to achieve a state of truly open science. Does the wording in such contracts violate ethics of COIs or explicitly limit or forbid individuals from serving on the editorial boards of two or more CJPs? Work contracts are bound by established codes of ethics $[55,56]$, and this applies equally to the employment of an editor by a journal or publisher, even if they work for free. Several cases of mass resignations from editorial boards described earlier in this paper offer some insight into the potential problems that can arise when editors serve CJPs, fail to reveal COIs, or are at a moral or ethical crossroads with the journal or publisher that they serve within their contractual bounds.

4. "If the number of manuscripts that the editor is expected to handle for each journal is high, their ability to assess all of them thoroughly and in a timely manner may be compromised." Many editors and EICs are themselves academics who conduct research and publish. They thus often have responsibilities associated with that work, and stress or pressure caused by severe time and other constraints. Effective, dedicated and timely editorial handling may be compromised by excessive tasks, overburdening editors and ultimately victimizing authors, e.g., in manuscript mishandling, excessively long editorial decisions [57] or unfair desk rejections [58].

\section{Conclusions, Limitations, and Challenges}

As can be appreciated from this discussion and the arguments set forth in this opinion piece, serving simultaneously as an editor or EIC for two or more CPJs invokes issues and conflicts related to loyalty, trust, unique dedication, COIs, morals and ethics, time and resource management and opacity versus transparency, aspects that need greater debate (and resolution) by academia - who may have differing opinions and viewpoints—and stricter regulation by policy makers.

Although this issue represents the author's opinion, wider debate is needed, in particular the decision and ultimate judgement of whether such positions on CJPs constitute unethical behavior, or if they are simply morally unacceptable publishing value systems [59], 
especially since COIs can be widespread and range widely, depending on the context [60]. In this opinion piece, several arguments pertaining to editors, their positions, and their responsibilities, are made: (1) given their position as gatekeepers of truth and the validity and integrity of academic information, editors have many responsibilities, primarily toward authors, journals, publishers, their academic community and finally the public; (2) for transparency, editors should declare any and all COIs on journals' editorial board pages and on their CVs; (3) serving on CJPs may constitute a professional and potentially financial COI; therefore, to remove any doubt, to be ethically safe and to reflect the fullest possible openness and transparency, such positions on CJPs should be declared in editor profiles on the editorial board of a journal's webpage and on an editor's CV; (4) even if COIs do not exist, the lack of COIs should be declared; and (5) wider debate is needed within the academic community to determine whether the failure of editors to declare COIs should be considered a form of misconduct. Given that editors are traditionally considered as the pinnacle of leadership in the publishing ecosystem with an established ethical core [61], and are, based on their leadership position alone, perceived as "good people" [62] and are also, to some extent, a type of public policy maker [63] since they establish and/or impose publishing policy for authors, the assessment of hidden COIs as a possible form of misconduct needs more debate and resolution. However, since "truth" cannot, and should not, be determined by blind trust alone, the existence or absence of COIs needs to be clearly indicated on editorial boards, as COI statements for each editor, including their position as editors of CJPs. Finally, given that there is a financial component to CJPs, especially for-profit ones, the legal consequences of hidden editorial COIs also require a spirited debate [64].

Clues to aid academic publishing could be drawn from some arguments that have been put forward regarding the issue of "disclosure" in the patient-physician relationship, resulting in bias caused by two claimed mechanisms: "strategic exaggeration (the tendency to provide more biased advice to counteract anticipated discounting) and moral licensing (the often unconscious feeling that biased advice is justifiable because the advisee has been warned)" [65]. While those arguments certainly do have weighting and importance in a clinical setting, their application cannot be literally transposed to the field of academic publishing. Within an academic context, "moral licensing" could be used to refer to situations where someone does something that is considered to be highly ethical but that allows the person to engage in unethical behavior, because they consider that it is "justified" by a previous ethical deed. The world of academic publishing evolved considerably in the past decade, and in these years, there are more actual or apparent threats to all parties (authors, editors, journals, publishers) and thus also to academic integrity, such as "predatory" publishing or paper mills and their lack of distinction or detection by even the most seasoned editors [66].

While some readers, especially editors who in fact do hold editorial positions on the editorial boards of CJPs, and editors who are in fact hiding or not declaring COIs might feel challenged—or threatened-by the perspectives in this commentary, they are invited to reflect on the following question: what ethical or moral advantage is there, what example is set and what message is sent to readers and authors if editors do not declare their COIs, even if they have none to declare? These provocative ideas may hopefully stimulate greater debate, inward reflection and eventual reform by such editors and the CJPs they serve, through a process of expanded moral awareness [67].

This paper offers an opinion regarding the issue of CJPs within the wider context of editors' positions, status and related responsibilities. As some journals or publishers seek to managerially restructure their publishing operations, or implement moral reengineering of their editorial ranks, the issues raised in this paper will become all the more pertinent. Undoubtedly, quantitative studies that assess the extent of the lack of written or stated COIs for editors are needed. These can be conducted in the future at various scales: within a journal, a publisher's journal fleet, academic field of study or geographic location. As one example of the ethical leadership setting a correct example, all COPE Trustees [68], 
who are the de facto leadership of this organization, have COI statements on their online profiles. Similarly, editors, who are also individuals that hold an ethical leadership position, could—and should—similarly display their COIs, including positions in CJPs.

Author Contributions: The author contributed entirely to the intellectual discussion underlying this paper, literature exploration, writing, reviews and editing and accepts responsibility for the content of this opinion piece. The author has read and agreed to the published version of the manuscript.

Funding: This research received no external funding.

Institutional Review Board Statement: Not applicable.

Informed Consent Statement: Not applicable.

Data Availability Statement: Not applicable.

Acknowledgments: The author thanks Panagiotis Tsigaris (Department of Economics, Thompson Rivers University, Kamloops, Canada) for verifying the blacklisting of the International Journal of Humanities and Social Science in Cabell's Predatory Reports, and for kindly providing feedback and commentary on an earlier version of the paper. The author also thanks the kind and useful feedback offered by Yuehong (Helen) Zhang (Zhejiang University Press, Hangzhou, China), Mario S. Di Bitetti (IBS, National Scientific and Technical Research Council, CONICET, Buenos Aires, Argentina) and Radha Holla (Alliance Against Conflict of Interest, Delhi, India) on earlier versions of the paper. Finally, the author thanks the strict, through-provoking and useful feedback and constructive praise and criticisms offered by four anonymous peer reviewers.

Conflicts of Interest: The author declares no conflict of interest of relevance to this topic.

\section{References}

1. Teixeira da Silva, J.A.; Al-Khatib, A. How are editors selected, recruited and approved? Sci. Eng. Ethics 2017, 23, 1801-1804. [CrossRef]

2. Lyon, L. Transparency: The emerging third dimension of open science and open data. Liber Q. 2016, 25, 153-171. [CrossRef]

3. Teixeira da Silva, J.A.; Dobránszki, J. Editors moving forward: Stick to academic basics, maximize transparency and respect, and enforce the rules. Recenti Progress. Med. 2018, 109, 263-266. [CrossRef]

4. Teixeira da Silva, J.A.; Tsigaris, P. Academics must list all publications on their CV. KOME 2018, 6, 94-99. [CrossRef]

5. Teixeira da Silva, J.A.; Dobránszki, J.; Bhar, R.H.; Mehlman, C.T. Editors should declare conflicts of interest. J. Bioethical Inq. 2019, 16, 279-298. [CrossRef] [PubMed]

6. ICMJE (International Committee of Medical Journal Editors). ICMJE form for Disclosure of Potential Conflicts of Interest. 2021. Available online: http:/ / www.icmje.org/conflicts-of-interest/ (accessed on 6 February 2021).

7. Lopez, M.; Chan, T.M.; Thoma, B.; Arora, V.M.; Trueger, N.S. The social media editor at medical journals: Responsibilities, goals, barriers, and facilitators. Acad. Med. 2019, 94, 701-707. [CrossRef] [PubMed]

8. Teixeira da Silva, J.A. Do zombie scientists and editors exhibit hubris, or blind courage? Focus Sci. 2016, 2, 2. [CrossRef]

9. Hojat, M.; Gonnella, J.S.; Caelleigh, A.S. Impartial judgment by the "gatekeepers" of science: Fallibility and accountability in the peer review process. Adv. Health Sci. Educ. 2003, 8, 75-96. [CrossRef] [PubMed]

10. Wager, E.; Kleinert, S. Why do we need international standards on responsible research publication for authors and editors? J. Glob. Health 2013, 3, 020301. [CrossRef]

11. Teixeira da Silva, J.A.; Dobránszki, J. The authorship of deceased scientists and their posthumous responsibilities. Sci. Ed. (CSE) 2015, 38, 98-100.

12. Teixeira da Silva, J.A.; Katavić, V. Free editors and peers: Squeezing the lemon dry. Ethics Bioeth. 2016, 6, 203-209. [CrossRef]

13. Trnka, S.; Trundle, C. Competing responsibilities: Reckoning personal responsibility, care for the other, and the social contract in contemporary life. In Competing Responsibilities: The Politics and Ethics of Contemporary Life; Trnka, S., Trundle, C., Eds.; Duke University Press: Durham, NC, USA, 2017; pp. 1-26.

14. Moore, D.A.; Lowenstein, G. Self-interest, automaticity, and the psychology of conflict of interest. Soc. Justice Res. 2004, 17, 189-202. [CrossRef]

15. Sezer, O.; Gino, F.; Bazerman, M.H. Ethical blind spots: Explaining unintentional unethical behavior. Curr. Opin. Psychol. 2015, 6, 77-81. [CrossRef]

16. Rahwan, Z.; Hauser, O.P.; Kochanowska, E.; Fasolo, B. High stakes: A little more cheating, a lot less charity. J. Econ. Behav. Organ. 2018, 152, 276-295. [CrossRef]

17. Bazerman, M.H.; Sezer, O. Bounded awareness: Implications for ethical decision making. Organ. Behav. Hum. Decis. Process. 2016, 136, 95-105. [CrossRef] 
18. Umphress, E.E.; Bingham, J.B. When employees do bad things for good reasons: Examining unethical pro-organizational behaviors. Organ. Sci. 2011, 22, 621-640. [CrossRef]

19. Rhee, J.J.; Schein, C.; Bastian, B. The what, how, and why of moralization: A review of current definitions, methods, and evidence in moralization research. Soc. Personal. Psychol. Compass 2019, 13, e12511. [CrossRef]

20. Vasquez, K.; Oswald, D.L.; Hammer, A. Being dishonest about our prejudices: Moral dissonance and self-justification. Ethics Behav. 2019, 29, 382-404. [CrossRef]

21. Hong, N.T. Unintentional unethical behavior: The mediating and moderating roles of mindfulness. Int. J. Ethics Syst. 2019, 36, 98-118. [CrossRef]

22. Sneider, T. Understanding dishonest behavior in organizations. In Proceedings of the 39th International Scientific Conference on Economic and Social Development_- "Sustainability from an Economic and Social Perspective”, Lisbon, Portugal, 29-30 April 2019; Lorga da Silva, A., Tomic, D., Grilec, A., Eds.; 2019; pp. 535-544.

23. Golestaneh, L.; Cowan, E. Hidden conflicts of interest in continuing medical education. Lancet 2017, 390, 2128-2130. [CrossRef]

24. Jordan, A.H.; Monin, B. From sucker to saint: Moralization in response to self-threat. Psychol. Sci. 2008, 19, 809-815. [CrossRef] [PubMed]

25. White, J.; Bandura, A.; Bero, L.A. Moral disengagement in the corporate world. Account. Res. 2009, 16, 41-74. [CrossRef]

26. Teixeira da Silva, J.A. Ethical exceptionalism: Can publishing rules be manipulated to give the impression of ethical publishing? Bangladesh J. Med. Sci. 2017, 16, 610-614. [CrossRef]

27. Roszkowska, P.; Melé, D. Organizational factors in the individual ethical behaviour. The notion of the "organizational moral structure". Humanist. Manag. J. 2020, in press. [CrossRef]

28. Houdek, P. Fraud and understanding the moral mind: Need for implementation of organizational characteristics into behavioral ethics. Sci. Eng. Ethics 2020, 26, 691-707. [CrossRef]

29. Conway, E.; Kotera, Y. Ethical judgement and intent in business school students: The role of the psyche? Int. J. Ethics Educ. 2020, 5, 151-186. [CrossRef]

30. Elm, D.R. Cognitive moral development in ethical decision-making. In Business Ethics (Business and Society 360, Vol. 3); Emerald Publishing Limited: Bentley, UK, 2019; pp. 155-177. [CrossRef]

31. Shu, L.L.; Mazar, N.; Gino, F.; Ariely, D.; Bazerman, M.H. Signing at the beginning makes ethics salient and decreases dishonest self-reports in comparison to signing at the end. Proc. Natl. Acad. Sci. USA 2012, 109, 15197-15200. [CrossRef]

32. Mendes, J.; Schepel, H. What a Journal Makes: As We Say Goodbye to the. European Law Journal VerfBlog. 2020. Available online: https://verfassungsblog.de/what-a-journal-makes-as-we-say-goodbye-to-the-european-law-journal/ (accessed on 6 February 2021).

33. Peterson, T. To the Editors, Diversity and Distributions; Wiley: Hoboken, NJ, USA, 2018; Available online: https://oanarchy. wordpress.com/2018/09/04/to-the-editors-diversity-and-distributions-and-wiley-publishers/ (accessed on 6 February 2021).

34. Wiley. Setting the Record Straight. In Wiley's Statement on Interference Accusations; John Wiley \& Sons, Inc.: Hoboken, NJ, USA, 2018; Available online: https:/ /authorservices.wiley.com/statements/DDI-statement.html (accessed on 6 February 2021).

35. McGill, B.; Araújo, M.; Franklin, J.; Linder, H.P.; Dawson, M.N. Writing the future of biogeography. Front. Biogeogr. 2018, 10, e41964. [CrossRef]

36. Reiner, V. Combinatorial Theory: A New Mathematician-Owned and Fully Open Access Journal. 2020. Available online: http:/ /fpsac.org/2020/09/13/CombinatorialTheoryJournal/ (accessed on 6 February 2021).

37. Reller, T. Addressing the Resignation of the Lingua Editorial Board. 2015. Available online: https://www.elsevier.com/connect/ addressing-the-resignation-of-the-lingua-editorial-board (accessed on 6 February 2021).

38. McKenzie, L. Editorial Mutiny at Elsevier Journal. 2015. Available online: https://www.insidehighered.com/news/2019/01/14 / elsevier-journal-editors-resign-start-rival-open-access-journal (accessed on 6 February 2021).

39. Dyer, O. Journal retracts article for plagiarism after editorial board members resign in protest. BMJ 2018, 360, k1386. [CrossRef]

40. Bakens, W.; Brager, G.; Burch, S.; Chan, E.; Cole, R.G.; Cooper, I.; Crawford, R.; Darby, S.; de Dear, R.; Donn, M.; et al. An Open Letter from Building Research \& Information EDITORIAL TEAM \& BOARD MEMBERS to Taylor \& Francis. 2018. Available online: https:/ / bricommunity.net/2018/02/19/an-open-letter-from-building-research-information-editorial-teamboard-members-to-taylor-francis / (accessed on 6 February 2021).

41. McDonald, R.I.; Salerno, J.M.; Greenaway, K.H.; Slepian, M.L. Motivated secrecy: Politics, relationships, and regrets. Motiv. Sci. 2020, 6, 61-78. [CrossRef]

42. Teixeira da Silva, J.A.; Dobránszki, J.; Tsigaris, P.; Al-Khatib, A. Predatory and exploitative behaviour in academic publishing: An assessment. J. Acad. Librariansh. 2019, 45, 102071. [CrossRef]

43. Teixeira da Silva, J.A. Responsibilities and rights of authors, peer reviewers, editors and publishers: A status quo inquiry and assessment. Asian Australas. J. Plant. Sci. Biotechnol. 2013, 7, 6-15.

44. Acemoglu, D.; Autor, D. Skills, tasks and technologies: Implications for employment and earnings. In Handbook of Labor Economics, 1st ed.; Ashenfelter, O., Card, D., Eds.; Elsevier: Amsterdam, The Netherlands, 2011; Volume 4, pp. 1043-1171. [CrossRef]

45. Farzin, Y.H. The effect of non-pecuniary motivations on labor supply. Q. Rev. Econ. Financ. 2009, 49, 1236-1259. [CrossRef]

46. Grudniewicz, A.; Moher, D.; Cobey, K.D.; Bryson, G.L.; Cukier, S.; Allen, K.; Ardern, C.; Balcom, L.; Barros, T.; Berger, M.; et al. Predatory journals: No definition, no defence. Nature 2019, 576, 210-212. [CrossRef] [PubMed] 
47. ASSAf; CHE; DHET; DST; NRF; USAf. Statement on ethical research and scholarly publishing practices. S. Afr. J. Sci. 2019, 115, 1. [CrossRef]

48. Ferris, L.E.; Winker, M.A. Ethical issues in publishing in predatory journals. Biochem. Med. 2017, 27, 279-284. [CrossRef]

49. Jessop, B. On academic capitalism. Crit. Policy Stud. 2018, 12, 104-109. [CrossRef]

50. CSE (Council of Science Editors). Editor Roles and Responsibilities. Section 2.1.6. (Policy added to the White Paper on May 4, 2018). 2018. Available online: http:/ /www.councilscienceeditors.org/resource-library/editorial-policies/white-paper-onpublication-ethics /2-1-editor-roles-and-responsibilities / (accessed on 6 February 2021).

51. Hausmann, L.; Schweitzer, B.; Middleton, F.A.; Schulz, J.B. Reviewer selection biases editorial decisions on manuscripts. J. Neurochem. 2018, 146, 21-46. [CrossRef]

52. Manchikanti, L.; Kaye, A.D.; Boswell, M.V.; Hirsch, J.A. Medical journal peer review: Process and bias. Pain Physician 2015, 18, E1-E14.

53. Moynihan, R.; Macdonald, H.; Heneghan, C.; Bero, L.; Godlee, F. Commercial interests, transparency, and independence: A call for submissions. BMJ 2019, 365, 1706. [CrossRef]

54. Hanretty, C. Media outlets and their moguls: Why concentrated individual or family ownership is bad for editorial independence. Eur. J. Commun. 2014, 29, 335-350. [CrossRef]

55. Chakrabarti, G.; Chatterjea, T. Being (un)ethical in workplaces: The theories and the empirics. In Ethics and Deviations in Decision-Making; Palgrave Macmillan: Singapore, 2020; pp. 13-80. [CrossRef]

56. Denney, V.P. Achieving business performance through ethical business practices. Bus. Stud. J. 2018, 9, 1-28.

57. Teixeira da Silva, J.A.; Dobránszki, J. Excessively long editorial decisions and excessively long publication times by journals: Causes, risks, consequences, and proposed solutions. Publ. Res. Q. 2017, 33, 101-108. [CrossRef]

58. Teixeira da Silva, J.A.; Al-Khatib, A.; Katavić, V.; Bornemann-Cimenti, H. Establishing sensible and practical guidelines for desk rejections. Sci. Eng. Ethics 2018, 24, 1347-1365. [CrossRef]

59. Kaptein, M. The appearance standard: Criteria and remedies for when a mere appearance of unethical behavior is morally unacceptable. Bus. Ethics A Eur. Rev. 2019, 28, 99-111. [CrossRef]

60. Fauser, B.C.J.M.; Macklon, N.S. May the colleague who truly has no conflict of interest now please stand up! Reprod. Biomed. Online 2019, 39, 541-544. [CrossRef]

61. Banks, G.C.; Fischer, T.; Gooty, J.; Stock, G. Ethical leadership: Mapping the terrain for concept cleanup and a future research agenda. Leadersh. Q. 2020, 101471. [CrossRef]

62. Feldman, Y.; Halali, E. Regulating "good" people in subtle conflicts of interest situations. J. Bus. Ethics 2019, 154, 65-83. [CrossRef]

63. Zamir, E.; Sulitzeanu-Kenan, R. Explaining self-interested behavior of public-spirited policy makers. Public Adm. Rev. 2018, 78, 579-592. [CrossRef]

64. Jenlink, P.M.; Jenlink, K.E. Education, ethics, and the law: Examining the legal consequences of unethical judgment. In The Palgrave Handbook of Education Law for Schools; Trimmer, K., Dixon, R., Findlay, S.Y., Eds.; Palgrave Macmillan: Cham, Switzerland, 2018; pp. 105-139. [CrossRef]

65. Loewenstein, G.; Sah, S.; Cain, D.M. The unintended consequences of conflict of interest disclosure. JAMA 2012, 307, 669-670. [CrossRef]

66. Teixeira da Silva, J.A. Paper mills and on-demand publishing: Risks to the integrity of journal indexing and metrics. Med. J. Armed Forces India 2021, 77, 119-120. [CrossRef] [PubMed]

67. Kim, J.; Loewenstein, J. Analogical encoding fosters ethical decision making because improved knowledge of ethical principles increases moral awareness. J. Bus. Ethics 2020, in press. [CrossRef]

68. COPE (Committee on Publication Ethics). COPE Trustees. 2021. Available online: https://publicationethics.org/about/trustees (accessed on 6 February 2021). 